\title{
Analisis Fisiko-Kimia Fruit Leather Pada Rambutan (Nephelium lappaceum) - Rosella (Hibiscus sabdariffa)
}

\author{
Ali Akbar Wahab ${ }^{1 *}$, Zulfardi Ashar $^{1}$, Dwi Maryana ${ }^{1}$ \\ Program Studi Teknlogi Hasil Pertanian, Fakultas Pertanian Universitas Teknologi Sulawesi, Jl. Talasalapang, Makassar, 90222
}

Email : *aliakbarwahab@gmail.com

\begin{abstract}
Abstrak
Penelitian ini bertujuan untuk mengetahui kombinasikan buah rambutan dan rosella, sehingga dapat menghasilkan fruit leather yang aman, bermanfaat bagi kesehatan dan memiliki warna yang menarik. Metode penelitian dilaksanakan melalui 2 tahapan yaitu Penelitian pendahuluan ini dilakukan untuk mendapatkan perbandingan jumlah buah yang tepat pada pembuatn fruit leather, Dengan perlakuan : A1 : $60 \%$ rambutan $+10 \%$ rosella, A2 : 50\% rambutan $+20 \%$ rosella, A3 : 40\% rambutan $+30 \%$ rosella. Selanjutnya dilakukan pengujian organoleptik metode hedonik. Kemudian hasil terbaik dari penelitian pendahuluan diberi perlakuan konsentrasi gula 40\%, 30\% dan 20\%. Hasil uji organoleptik dengan menggunakan metode hedonic terhadap produk fruit leather rambutan rosella selanjutnya dilakukan uji kimia meliputi total asam, pH, kadar air dan uji organoleptik. Pembuatan Fruit Leathe Rambutan-Rosella perlakuan terbaik berdasarkan analisis kimia yang dilakukan terdapat pada perlakuan A3 (Rambutan 40\% + Rosella 30\% + Gula 20\%) dengan rata-rata kadar air 15,08, rata-rata total asam 1,67 dan rata-rata tingkat keasaman $(\mathrm{pH}) 3,52$. Dan perlakuan terbaik berdasarkan hasil uji organoleptik berdasarkan warna, aroma, rasa dan tekstur yang dilakukan perlakuan terbaik terdapat pada perlakuan A3 (Rambutan 40\% + Rosella 30\% + Gula 20\%) dengan rata-rata tingkat kesukaan pada warna 3,83, aroma 3,47, rasa, 3,68 dan Tekstur 3,64.
\end{abstract}

Keywords : Fruit Leather ; Rambutan ; Rosella ; Gula ; Organoleptik

\section{Pendahuluan}

Buah-buahan merupakan salah satu organ pada tumbuhan yang memiliki berbagai jenis bentuk, rasa, dan manfaat. Selain itu buah-buahan tidak selalu dikonsumsi dalam bentuk segar, tetapi sebagian besar diolah menjadi berbagai bentuk dan jenis makanan. Pengolahan ini bertujuan untuk memperpanjang masa simpan dan meningkatkan aneka ragam produk. Buah-buahan ini dapat diolah menjadi berbagai bentuk makanan seperti selai, keripik, dodol dan manisan. Produk manisan ini dapat berupa manisan basah atau manisan kering. Selain itu buah-buahan dapat dibuat sebagai produk fruit leather.

Fruit leather merupakan produk jenis makanan yang berasal dari daging buah yang dihancurkan dan dikeringkan. Proses pengeringan bisa dilakukan dengan penjemuran atau juga menggunakan pemanasan suhu panas 50-600C. Fruit leather memiliki daya simpan sampai 12 bulan, bila di simpan pada kondisi penyimpanan yang sesuai.

Bahan baku fruit leather dapat berasal dari berbagai jenis buah-buahan tropis ataupun subtropis dengan kandungan serat yang cukup tinggi seperti pisang, papaya, manga, nenas, apel, nangka, rambutan dan sebagainya. Rambutan merupakan salah satu jenis buah yang produksinya cukup tinggi dan disukai oleh masyarakat. Selain itu rambutan juga memiliki banyak manfaat bagi kesehatan, diantaranya meningkatkan energi, kaya vitamin C, membantu menurunkan berat badan dan meningkatkan kekuatan tulang.
Rosella mengandung beberapa zat yang sangat penting bagi kesehatan. Tiap $100 \mathrm{~g}$ kelopak bunga segar mengandung 260-280 mg vitamin C. Selain itu, rosella juga mengandung vitamin $\mathrm{D}$, vitamin $\mathrm{B} 1, \mathrm{~B} 2$, zat besi, asam amino, polisakarida, omega 3 dan kalsium dalam jumlah yang cukup tinggi $(486 \mathrm{mg} / 100 \mathrm{~g})$. Rasa asam dalam bunga rosella merupakan perpaduan berbagai jenis asam seperti asam askrobat (vitamin C), asam sitrata, dan asam malat yang juga bermanfaat bagi tubuh (Erianto, 2009 dalam Safitri, 2012).

Kandungan serat dalam bunga rosella pun cukup tinggi yang berperan dalam melancarkan sistem pembuangan dan menurunkan kadar kolestrol dalam darah. Selain kandungan zat dan serat rosella juga terdapat kandungan bahan aktif seperti grossy peptin,

anthocyanin, gluside hibiscin dan flavonoid yang bermanfaat mencegah kanker, mengendalikan tekanan darah dan melancarkan peredaran darah (Erianto, 2009 dalam Safitri, 2012).

Berdasarkan pemaparan tersebut, maka penelitian ini dilakukan untuk mengetahui kombinasi buah rambutan dan rosella, sehingga dapat menghasilkan fruit leather yang aman, bermanfaat bagi kesehatan dan memiliki warna yang menarik.

\section{Metode Penelitian} yaitu :

Metode penelitian dilaksanakan melalui 2 tahapan 
- Penelitian pendahuluan

Penelitian pendahuluan ini dilakukan untuk mendapatkan perbandingan jumlah buah yang tepat pada pembuatn fruit leather, Dengan perlakuan : A1 : $60 \%$ rambutan $+10 \%$ rosella, A2 : 50\% rambutan $+20 \%$ rosella, A3 : $40 \%$ rambutan $+30 \%$ rosella. Selanjutnya dilakukan pengujian organoleptik metode hedonik.

\section{- Penelitian utama}

Hasil terbaik dari penelitian pendahuluan diberi perlakuan konsentrasi gula 20\%, 30\% dan 40\%. Kemudian dari organoleptik dengan menggunakan metode hedonic terhadap produk fruit leather rambutan rosella selanjutnya dilakukan uji kimia meliputi total asam, $\mathrm{pH}$, kadar air dan uji organoleptik.

\section{Hasil dan Pembahasan}

\subsection{Penelitian Pendahuluan}

Pada penelitian pendahuluan ini dilakukan untuk mendapatkan perbandingan jumlah buah yang tepat

pada pembuatan fruit leather. Uji organoleptik adalah pengujian yang menggunkan indera manusia untuk

mengukur tekstur, penampakan, aroma dan flavour produk pangan (Pertiwi, 2013). Pengujian dilakukan

dengan menggunakan uji skoring terhadap parameter warna, aroma, rasa dan tekstur.

Dimana Hasil uji organoleptik diketahui bahwa rata-rata untuk kesukaan terhadap warna skor tertinggi pada perlakuan A3 (40\% rambutan $+30 \%$ rosella) dengan rata-rata nilai 3,45 . Rata-rata skor tertinggi untuk kesukaan terhadap aroma adalah perlakuan A1 (60\% rambutan $+10 \%$ rosella) dengan rata-rata nilai 2,73 . Sedangkan rata-rata skor tetinggi untuk kesukaan terhadap rasa adalah perlakuan A3 (40\% rambutan $+30 \%$ rosella) dengan rata-rata nilai 3,27 . Skor rata-rata tertinggi untuk kesukaan terhadap tekstur pada perlakuan A3 $(40 \%$ rambutan $+30 \%$ rosella) dengan rata-rata nilai 3,55 (Tabel.1). Ini sesuai dengan pendapat Winarno dalam Safitri (2012) mengatakan bahwa uji organoleptik digunakan untuk menentukan suatu formulasi terbaik berdasarkan tingkat kesukaan dengan menggunakan indera manusia.

Tabel 1. Hasil uji organoleptik penelitian pendahuluan

\begin{tabular}{cccc}
\hline Uji & \multicolumn{3}{c}{ Rata-Rata Perlakuan } \\
\cline { 2 - 4 } Organoleptik & A1 & A2 & A3 \\
\hline Warna & 2.91 & 3.36 & 3.45 \\
Aroma & 2.73 & 2.36 & 2.55 \\
Rasa & 3.09 & 2.91 & 3.27 \\
Tekstur & 2.91 & 3.36 & 3.55 \\
\hline
\end{tabular}

Sumber : Data Hasil Penelitian 2020

\subsection{Penelitian Utama}

Pada penelitian utama ini menggunakan hasil terbaik dari penelitian pendahuluan, dimana hasil terbaik dari penelitian pendahuluan yaitu perlakuan A3 (40\% Rambutan $+30 \%$ Rosella). Hasil terbaik dari penelitian pendahuluan ini menjadi dasar dalam pembuatan fruit leather yang akan ditambahkan perlakuan konsentrasi gula 40\%, 30\% dan $20 \%$.

\section{$>$ Analisis Total Asam}

Berdasarkan hasil analisi total asam pembuatan fruit leather didapatkan hasil total asam untuk setiap perlakuan (Tabel 2) yaitu perlakuan A1 dengan rata-rata total asam 2,72, perlakuan A2 dengan rata-rata total asam 1,79 dan perlakuan A3 dengan rata-rata total asam 1,69. Pada pembuatan fruit leather ini ditambahkan asam sitrat, dengan tujuan memberikan rasa asam segar pada fruit leather, selain itu bermanfaat juga sebagai pengawet untuk memperpanjang umur simpan fruit leather. Menurut Anonim (2011) keasaman asam sitrat disebabkan karena adanya tiga gugus karboksil $\mathrm{COOH}$ yang dapat melepaskan proton ke dalam larutan. Jika hal ini terjadi, ion yang dihasilkan disebut ion sitrat. Sukardjo (1997) dan Saati (2010) menambahkan bahwa apabila konsentrasi ion $\mathrm{H}+$ lebih besar dari pada ion $\mathrm{OH}$ - maka larutan akan bersifat asam dan apabila konsentrasi ion $\mathrm{H}+$ lebih kecil dari pada ion $\mathrm{OH}-$ maka larutan akan bersifat basa. Menurut Anonim (2011) asam sitrat aman digunakan dalam bahan pangan walaupun dalam jumlah besar karena asam sitrat bisa dimetabolisme dan dikeluarkan dari tubuh.

\section{$>$ Analisa Tingkat Keasaman}

Hasil Analisa tingkat keasaman $(\mathrm{pH})$ menunjukkan bahwa pembuatan fruit leather rambutan + rosella menjukkan tingkat keasaman $(\mathrm{pH})$ rata-rata berkisar antara $2,82-3,52 \%$. Dimana tingkat keasaman terendah terdapat pada perlakuan A1 dengan rata-rata tingkat keasaman $(\mathrm{pH})$ 2,82 dan tingkat keasaman tertinggi terdapat pada perlakuan A3 dengan rata-rata tingkat keasaman 3,52. Ini sesuai dengan pendapat Fardiaz (1992) pH atau keasamaan makanan dipengaruhi oleh asam yang terdapat pada bahan makanan secara alami. Hasil penelitian Safitri (2012) melakukan substitusi buah mangga dengan kelopak bunga rosela (35\% : $25 \%$ ) yang mencapai $\mathrm{pH}$ sebesar 3,45 lebih rendah dibandingkan dengan derajat keasaman fruit leather buah sirsak kombinasi buah melon. Hal ini disebabkan oleh bahan baku yang digunakan. Buah sirsak dan melon menghasilkan pH lebih tinggi yaitu dibandingkan buah mangga dan kelopak bunga rosela pada penelitian Safitri yang menyumbangkan $\mathrm{pH}$ lebih rendah

\section{$>$ Analisa Kadar air}

Berdasarkan hasil analisa kadar air yang dilakukan pada peneltian ini di dapatkan rata-rata kadar air pada tiap perlakuan yaitu A1 rata-rata kadar air sebesar 20,25\%, A2 rata-rata kadar air sebesar $17,77 \%$ dan $\mathrm{A} 3$ rata-rata kadar air $15,08 \%$. Ini sesuai dengan pendapat Wirayuna , et al. (2014) dan Fauziah (2015) yang menyatakan bahwa kadar gula dan kadar serat yang terkandung didalam bahan sangat mempengaruhi kadar air fruit leather. Semakin tinggi gula yang terkandung didalam bahan, maka semakin tinggi pula kadar air yang dihasilkan. Pada penelitian ini, peningkatan kadar air ini lebih disebabkan oleh meningkatnya 
kemampuan bahan dalam mengikat air karena semakin tingginya kandungan gula yang terkandung di dalam bahan. Wirayuna, et al. (2014), dalam penelitiannya menyatakan bahwa jumlah gula yang terkandung di dalam bahan mengakibatkan peningkatan kemampuan mengikat air di dalam bahan.

\section{$>$ Uji Organoleptik}

Pengujian dilakukan dengan menggunakan uji skoring terhadap parameter warna, aroma, rasa dan tekstur. Dimana Hasil uji organoleptik diketahui bahwa rata-rata untuk kesukaan terhadap warna skor tertinggi pada perlakuan A3 dengan rata-rata nilai 3,83. Rata-rata skor tertinggi untuk kesukaan terhadap aroma adalah perlakuan A2 dengan ratarata nilai 3,56. Sedangkan rata-rata skor tetinggi untuk kesukaan terhadap rasa adalah perlakuan A3 dengan rata-rata nilai 3,68. Skor rata-rata tertinggi untuk kesukaan terhadap tekstur pada perlakuan A3 dengan rata-rata nilai 3,64. Ini sesuai dengan pendapat Winarno dalam Safitri (2012) mengatakan bahwa uji organoleptik digunakan untuk menentukan suatu formulasi terbaik berdasarkan tingkat kesukaan dengan menggunakan indera manusia.

Tabel 2. Rekapitulasi Hasil Penelitian berdasarkan Kadar air, Total Asam, pH dan Uji Organoleptik (Warna, Aroma, Rasa dan Tekstur)

\begin{tabular}{|c|c|c|c|c|c|c|c|}
\hline \multirow{2}{*}{ Perlakuan } & \multirow{2}{*}{ Kadar Air } & \multirow{2}{*}{$\begin{array}{l}\text { Total } \\
\text { Asam }\end{array}$} & \multirow{2}{*}{ pH } & \multicolumn{4}{|c|}{ Uji Organoleptik } \\
\hline & & & & Warna & Aroma & Rasa & Tekstur \\
\hline$\underset{(40: 30: 40)}{A 1}$ & 20,25 & 2,72 & 2,82 & 3,13 & 3,27 & 3,06 & 3,43 \\
\hline $\begin{array}{c}\text { A2 } \\
(40: 30: 30)\end{array}$ & 17,77 & 1,79 & 3,10 & 3,57 & 3,56 & 3,35 & 3,58 \\
\hline $\begin{array}{c}A 3 \\
(40: 30: 20)\end{array}$ & 15,08 & 1,67 & 3,52 & 3,83 & 3,47 & 3,68 & 3,64 \\
\hline
\end{tabular}

Sumber : Data sekunder hasil penelitian Pembuatan Fruit Leather,2020

\section{Kesimpulan}

Dari penelitian yang telah dilakukan dapat disimpulkan bahwa pembuatan Fruit Leather RambutanRosella perlakuan terbaik berdasarkan analisis kimia yang dilakukan terdapat pada perlakuan A3 (Rambutan 40\% + Rosella 30\% + Gula 20\%) dengan rata-rata kadar air 15,08, rata-rata total asam 1,67 dan rata-rata tingkat keasaman (pH) 3,52.

Perlakuan terbaik berdasarkan hasil uji organoleptik berdasarkan warna, aroma, rasa dan tekstur yang dilakukan perlakuan terbaik terdapat pada perlakuan A3 (Rambutan $40 \%$ + Rosella $30 \%$ + Gula 20\%) dengan rata-rata tingkat kesukaan pada warna 3,83, aroma 3,47, rasa, 3,68 dan Tekstur 3,64.

\section{Ucapan Terima Kasih}

Terima kasih kepada bapak rector Universitas Teknologi Sulawesi, Rekan Dosen Fakultas Pertanian Program Studi Teknologi Hasil Pertanian atas dukungan dan bantuannya, sehingga peneltian ini dapat berjalan dengan lancar walaupun diketahui bahwa banyaknya kendala yang dihadapi oleh penulis dalam pelaksanaan penelitan yang di akibatkan oleh pandemic covid-19 yang menyerag hampir segala sektor.

\section{Daftar Pustaka}

Fardiaz, S. 1992. Mikrobiologi Pengolahan Pangan. Departemen Pendidikan dan Kebudayaan. Direktorat Jendral Pendidikan Tinggi. Pusat Antar Universitas Pangan dan Gizi. IPB. Bogor.

Fauziah E. 2015. Kajian Karakteristik Sensoris dan Fisikokimia Fruit Leather Pisang Tanduk (Musacorniculata) dengan Penambahan Berbagai Konsentrasi Karagenan. Jurnal Aplikasi Teknologi Pangan 4 (1).

Pertiwi, M. 2013. Teknologi Buah dan Sayur (Fruit Leather). Ilmu dan Teknologi Pangan. Universitas Jendral Soedirman. Purwokerto.

Safitri, A.A, 2012. Studi Pembatan Fruit Leather Mangga-Rosella. Skripsi Jurusan Teknologi Hasil Pertanian. Universitas Hasanudddin. Makassar.

Yusmita, L. Wijayanti R. 2018. Pengaruh Penambahan Jerami Nangka (Artocarpus Heterophyllus Lam) Terhadap Karakteristik Fruit Leather Mangga (Mangifera Indica L). Jurnal Teknologi dan Industri Pertanian Indonesia (10) 1

Wirayuna, A. K., Y. Pratiningsih dan S. Yuwanti. 2014. Karakterisasi Fruit Leather Sukun (Artocarpus communis) - Sirsak (Annona muricata Linn). Berkala Ilmiah Pertanian 1 (1): 26-31 